\title{
Study of water quality analysis and evaluation of Hengshui Lake
}

\author{
Yuhua Gao ${ }^{1,2,3}$, Haihua $\mathrm{Li}^{1,2}$, Yuxuan Zheng ${ }^{1,4}$, Ruhui Guo ${ }^{1,2}$ and Zhenfa Liu ${ }^{1,2, ~ *}$ \\ ${ }^{1}$ Institute of Energy Resources, Hebei Academy of Sciences, Shijiazhuang 050081, China \\ ${ }^{2}$ Hebei Engineering Research Center for Water Saving in Industry, Shijiazhuang 050081, China \\ ${ }^{3}$ Hebei Key Laboratory of Wetland Ecology and Conservation, Hengshui 053000, China \\ ${ }^{4}$ School of Chemical Engineering and Technology, Hebei University of Technology, Tianjin 300130, China
}

\begin{abstract}
The water quality of Hengshui Lake in different regions and at different times was analyzed. According to the data analysis results of chemical oxygen demand (COD), biochemical oxygen demand (BOD5), ammonia nitrogen $\left(\mathrm{NH}_{3}-\mathrm{N}\right)$, total nitrogen $(\mathrm{TN})$, total organic carbon (TOC), total phosphorus (TP), calcium ion content, total hardness, chloride ion content, $\mathrm{pH}$ value and conductivity of Hengshui Lake water samples, the water quality of Hengshui Lake was evaluated and analyzed. The results showed that the pollution of Hengshui Lake was mainly organic matter pollution, especially non-biodegradable organic matter pollution. The value of TN was higher than the Class III water, which showed that the self purification capacity of Hengshui Lake water body was weaker. The water quality of Hengshui Lake was better, but the treatment of organic pollution should be paid attention to.
\end{abstract}

\section{Introduction}

Hengshui Lake is a National Nature Reserve, which is covering an area of $268.08 \mathrm{~km}^{2}$. Hengshui Lake is a wetland ecosystem with swamp, water area, beach and meadow. Hengshui Lake is located in the south of North China Plain, which is an inland wetland. It is a typical urban lake and a still water ecosystem ${ }^{[1,2]}$. The lake water has a long retention time and slow flow. The total water storage area of the Hengshui Lake is $75 \mathrm{~km}^{2}$. The whole lake is divided into two parts, which are East Lake and West Lake. The East Lake stores water all the year round, while the West Lake includes water surface, beach, wetland and meadow. The lakeside has broadleaved forest land, and the surface water layer is the symbiotic habitat of fish, reed, cattail and lotus ${ }^{[3-5]}$.

The water source of Hengshui Lake is mainly from the Yellow River, Yuecheng Reservoir and Huangbizhuang reservoir. In addition, the natural precipitation also provides some supplement. Due to the great change of precipitation in Hengshui Lake catchment area, the interannual variation of water level and storage capacity of Hengshui Lake also changes greatly ${ }^{[6,7]}$. With the development of economy, water consumption is increasing rapidly, and water pollution is more serious, which makes fresh water resources is more scarce. It can be seen that the water quality of Hengshui Lake has a great impact on the ecological environment of the area ${ }^{[8,9]}$. In this paper, the water quality of Hengshui Lake in different ecological areas and different times is analyzed to evaluate the current situation of water pollution and eutrophication treatment of Hengshui Lake.

\section{Experimental}

\subsection{Water samples collection}

Water samples were collected from six different locations of Hengshui Lake, and samples were taken every two months from May 2020 to May 2021, of which no samples were taken in January 2021 (icebound season). GPS was used to fix position of water intake of Hengshui Lake every time in order to ensure the accuracy of water intake location. The positions of water intake of Hengshui Lake were shown in Table 1. $5 \mathrm{~L}$ water sample were took every time after washing the plastic bucket with lake water for 3 times. The collected water samples will be treated as required.

Table 1. The positions of water intake of Hengshui Lake.

\begin{tabular}{|c|c|c|}
\hline \multirow{2}{*}{$\begin{array}{c}\text { Serial number } \\
\text { of water } \\
\text { samples }\end{array}$} & \multicolumn{2}{|c|}{$\begin{array}{c}\text { Position of water intake of } \\
\text { Hengshui Lake }\end{array}$} \\
\cline { 2 - 3 } & North latitude & East longitude \\
\hline 1 & $37^{\circ} 38^{\prime} 58^{\prime \prime}$ & $115^{\circ} 38^{\prime} 37^{\prime \prime}$ \\
\hline 2 & $37^{\circ} 38^{\prime} 54^{\prime \prime}$ & $115^{\circ} 38^{\prime} 21^{\prime \prime}$ \\
\hline 3 & $37^{\circ} 38^{\prime} 37^{\prime \prime}$ & $115^{\circ} 37^{\prime} 53^{\prime \prime}$ \\
\hline 4 & $37^{\circ} 38^{\prime} 12^{\prime \prime}$ & $115^{\circ} 37^{\prime} 57^{\prime \prime}$ \\
\hline 5 & $37^{\circ} 38^{\prime} 22^{\prime \prime}$ & $115^{\circ} 38^{\prime} 15^{\prime \prime}$ \\
\hline 6 & $37^{\circ} 38^{\prime} 37^{\prime \prime}$ & $115^{\circ} 38^{\prime} 22^{\prime \prime}$ \\
\hline
\end{tabular}

\footnotetext{
* Corresponding author: 1zf63@sohu.com
} 


\subsection{Water quality determination method}

The total carbon (TC) in water quality can be divided into total organic carbon (TOC) and inorganic carbon (IC). In order to determine the TOC in water quality, TC is usually measured first and then calculated by formula $\mathrm{TOC}=\mathrm{TC}-\mathrm{IC}$. Because the IC in the lake water is less, we usually use the direct method. The method is as follows: IC in the water sample to be detected is removed by acidification and aeration, and then the water sample is injected into the high-temperature combustion tube to directly determine the do not purge organic carbon (NPOC). Therefore, the NPOC measured is TOC.

The chemical oxygen demand (COD), biochemical oxygen demand (BOD5), ammonia nitrogen $\left(\mathrm{NH}_{3}-\mathrm{N}\right)$ and total nitrogen (TN) were determined through water quality analyzer. Total phosphorus (TP) was determined through ammonium molybdate spectrophotometry.

EDTA titration method was used to determine calcium ion content and total hardness of Hengshui Lake water samples. The specific determination method was as follows: First filter the water sample, then take $25 \mathrm{~mL}$ filtered water sample, add $20 \mathrm{~mL}$ deionized water, and successively add $1 \mathrm{~mL} 20 \%$ sodium hydroxide solution and an appropriate amount of calcium-carboxylic acid indicator. Finally, titrate with EDTA standard solution and calculate the calcium ion content. The determination method of total hardness of water samples ws similar to the method for the determination of calcium ion content. First filter the water sample, then take $25 \mathrm{~mL}$ filtered water sample, add $20 \mathrm{~mL}$ deionized water, and successively add $5 \mathrm{~mL}$ ammonia-ammonium chloride buffer solution and an appropriate amount of chrome black $\mathrm{T}$ indicator solution. Finally, titrate with EDTA standard solution and calculate the total hardness.
Silver nitrate titration method was used to determine chloride ion content of Hengshui Lake water samples. The specific determination method was as follows: First filter the water sample, then take $25 \mathrm{~mL}$ filtered water sample, add $20 \mathrm{~mL}$ deionized water, and add an appropriate amount of phenolphthalein indicator solution. Finally, titrate with silver nitrate standard solution to calculate the chloride ion content.

\subsection{Water quality evaluation}

According to the data analysis results of chemical oxygen demand, biochemical oxygen demand, ammonia nitrogen, total nitrogen, total organic carbon, total phosphorus, calcium ion content, total hardness, chloride ion content, $\mathrm{pH}$ value and conductivity of Hengshui Lake water samples, the water quality of Hengshui Lake in different regions and at different times was evaluated and analyzed.

\section{Results and discussion}

\subsection{Determination results and analysis of TOC and TP}

It can be seen from Table 2 that the determination results of TOC and TP of water samples of six different locations and at different times was different. The value of TOC was comparatively higher. TOC refers to the total amount of dissolved and suspended organic carbon in water. It was usually used as an important basis for evaluating the pollution degree of organic matter in water. But the value of TP was comparatively lower. This showed that the pollution of Hengshui Lake was mainly organic matter pollution.

Table 2. Determination results of TOC and TP.

\begin{tabular}{|c|c|c|c|c|c|c|c|c|c|c|c|c|}
\hline \multirow{2}{*}{$\bigvee_{\text {Samples }}^{\text {Date }}$} & \multicolumn{2}{|c|}{2020.05} & \multicolumn{2}{|c|}{2020.07} & \multicolumn{2}{|c|}{2020.09} & \multicolumn{2}{|c|}{2020.11} & \multicolumn{2}{|c|}{2021.03} & \multicolumn{2}{|c|}{2021.05} \\
\hline & $\begin{array}{c}\text { TOC } \\
(\mathrm{mg} / \mathrm{L})\end{array}$ & $\begin{array}{c}\text { TP } \\
(\mathrm{mg} / \mathrm{L})\end{array}$ & $\begin{array}{c}\text { TOC } \\
(\mathrm{mg} / \mathrm{L})\end{array}$ & $\begin{array}{c}\text { TP } \\
(\mathrm{mg} / \mathrm{L})\end{array}$ & $\begin{array}{c}\text { TOC } \\
(\mathrm{mg} / \mathrm{L})\end{array}$ & $\begin{array}{c}\text { TP } \\
(\mathrm{mg} / \mathrm{L})\end{array}$ & $\begin{array}{c}\text { TOC } \\
(\mathrm{mg} / \mathrm{L})\end{array}$ & $\begin{array}{c}\text { TP } \\
(\mathrm{mg} / \mathrm{L})\end{array}$ & $\begin{array}{c}\text { TOC } \\
(\mathrm{mg} / \mathrm{L})\end{array}$ & $\begin{array}{c}\text { TP } \\
(\mathrm{mg} / \mathrm{L})\end{array}$ & $\begin{array}{c}\text { TOC } \\
(\mathrm{mg} / \mathrm{L})\end{array}$ & $\begin{array}{c}\text { TP } \\
(\mathrm{mg} / \mathrm{L})\end{array}$ \\
\hline 1 & 8.4 & 0.017 & 7.8 & 0.014 & 6.5 & 0.05 & 5.2 & 0.012 & 7.6 & 0.016 & 6.3 & 0.018 \\
\hline 2 & 5.7 & 0.015 & 8.1 & 0.014 & 9.4 & 0.083 & 4.2 & 0.012 & 7.5 & 0.015 & 6.0 & 0.017 \\
\hline 3 & 8.4 & 0.023 & 8.6 & 0.016 & 8.6 & 0.087 & 4.4 & 0.018 & 6.8 & 0.015 & 6.2 & 0.019 \\
\hline 4 & 7.4 & 0.014 & 7.3 & 0.017 & 8.7 & 0.079 & 7.2 & 0.007 & 7.9 & 0.014 & 6.2 & 0.018 \\
\hline 5 & 7.8 & 0.021 & 8.8 & 0.013 & 9.6 & 0.085 & 9.3 & 0.020 & 6.8 & 0.020 & 5.8 & 0.015 \\
\hline 6 & 8.5 & 0.017 & 9.2 & 0.015 & 9.1 & 0.078 & 7.5 & 0.007 & 7.2 & 0.018 & 6.1 & 0.016 \\
\hline
\end{tabular}


Table 3. Determination results of COD and BOD5.

\begin{tabular}{|c|c|c|c|c|c|c|c|c|c|c|c|c|}
\hline \multirow{2}{*}{ Date } & \multicolumn{2}{|c|}{2020.05} & \multicolumn{2}{|c|}{2020.07} & \multicolumn{2}{|c|}{2020.09} & \multicolumn{2}{|c|}{2020.11} & \multicolumn{2}{|c|}{2021.03} & \multicolumn{2}{|c|}{2021.05} \\
\hline & $\begin{array}{c}\text { COD } \\
(\mathrm{mg} / \mathrm{L})\end{array}$ & $\begin{array}{l}\text { BOD5 } \\
(\mathrm{mg} / \mathrm{L})\end{array}$ & $\begin{array}{c}\text { COD } \\
(\mathrm{mg} / \mathrm{L})\end{array}$ & $\begin{array}{l}\text { BOD5 } \\
(\mathrm{mg} / \mathrm{L})\end{array}$ & $\begin{array}{c}\text { COD } \\
(\mathrm{mg} / \mathrm{L})\end{array}$ & $\begin{array}{l}\text { BOD5 } \\
(\mathrm{mg} / \mathrm{L})\end{array}$ & $\begin{array}{c}\text { COD } \\
(\mathrm{mg} / \mathrm{L})\end{array}$ & $\begin{array}{l}\text { BOD5 } \\
(\mathrm{mg} / \mathrm{L})\end{array}$ & $\begin{array}{c}\text { COD } \\
(\mathrm{mg} / \mathrm{L})\end{array}$ & $\begin{array}{l}\text { BOD5 } \\
(\mathrm{mg} / \mathrm{L})\end{array}$ & $\begin{array}{c}\text { COD } \\
(\mathrm{mg} / \mathrm{L})\end{array}$ & $\begin{array}{l}\text { BOD5 } \\
(\mathrm{mg} / \mathrm{L})\end{array}$ \\
\hline 1 & 28.59 & 3.28 & 26.45 & 2.16 & 22.35 & 1.12 & 34.61 & 1.62 & 38.06 & 1.87 & 46.65 & 2.69 \\
\hline 2 & 28.59 & 2.84 & 27.61 & 1.68 & 24.28 & 1.35 & 46.64 & 1.73 & 47.26 & 1.91 & 55.68 & 2.17 \\
\hline 3 & 31.60 & 3.56 & 42.28 & 2.53 & 48.14 & 2.67 & 33.11 & 2.14 & 36.17 & 2.23 & 43.64 & 2.68 \\
\hline 4 & 36.12 & 2.14 & 28.17 & 1.66 & 22.38 & 1.24 & 30.10 & 1.57 & 35.24 & 1.68 & 49.66 & 2.25 \\
\hline 5 & 57.19 & 2.97 & 40.68 & 2.64 & 36.26 & 1.83 & 33.11 & 1.76 & 34.62 & 1.84 & 43.64 & 2.36 \\
\hline 6 & 56.50 & 2.65 & 48.24 & 2.11 & 50.51 & 2.15 & 24.08 & 2.02 & 30.49 & 2.13 & 45.15 & 2.83 \\
\hline
\end{tabular}

Table 4. Determination results of $\mathrm{NH}_{3}-\mathrm{N}$ and TN.

\begin{tabular}{|c|c|c|c|c|c|c|c|c|c|c|c|c|}
\hline \multirow{2}{*}{$\bigvee_{\text {Samples }}^{\text {Date }}$} & \multicolumn{2}{|c|}{2020.05} & \multicolumn{2}{|c|}{2020.07} & \multicolumn{2}{|c|}{2020.09} & \multicolumn{2}{|c|}{2020.11} & \multicolumn{2}{|c|}{2021.03} & \multicolumn{2}{|c|}{2021.05} \\
\hline & $\begin{array}{l}\mathrm{NH}_{3}-\mathrm{N} \\
(\mathrm{mg} / \mathrm{L})\end{array}$ & $\begin{array}{c}\text { TN } \\
(\mathrm{mg} / \mathrm{L})\end{array}$ & $\begin{array}{l}\mathrm{NH}_{3}-\mathrm{N} \\
(\mathrm{mg} / \mathrm{L})\end{array}$ & $\begin{array}{c}\text { TN } \\
(\mathrm{mg} / \mathrm{L})\end{array}$ & $\begin{array}{l}\mathrm{NH}_{3}-\mathrm{N} \\
(\mathrm{mg} / \mathrm{L})\end{array}$ & $\begin{array}{c}\text { TN } \\
(\mathrm{mg} / \mathrm{L})\end{array}$ & $\begin{array}{l}\mathrm{NH}_{3}-\mathrm{N} \\
(\mathrm{mg} / \mathrm{L})\end{array}$ & $\begin{array}{c}\text { TN } \\
(\mathrm{mg} / \mathrm{L})\end{array}$ & $\begin{array}{l}\mathrm{NH}_{3}-\mathrm{N} \\
(\mathrm{mg} / \mathrm{L})\end{array}$ & $\begin{array}{c}\text { TN } \\
(\mathrm{mg} / \mathrm{L})\end{array}$ & $\begin{array}{l}\mathrm{NH}_{3}-\mathrm{N} \\
(\mathrm{mg} / \mathrm{L})\end{array}$ & $\begin{array}{c}\text { TN } \\
(\mathrm{mg} / \mathrm{L})\end{array}$ \\
\hline 1 & 0.43 & 1.09 & 0.55 & 0.94 & 0.23 & 0.70 & 0.46 & 0.97 & 0.65 & 1.26 & 0.50 & 1.21 \\
\hline 2 & 0.65 & 1.09 & 0.68 & 0.96 & 0.32 & 0.74 & 0.42 & 0.95 & 0.72 & 1.24 & 0.68 & 1.20 \\
\hline 3 & 0.59 & 1.04 & 0.71 & 1.02 & 0.30 & 0.84 & 0.48 & 0.96 & 0.57 & 1.15 & 0.36 & 1.18 \\
\hline 4 & 0.55 & 1.18 & 0.54 & 0.86 & 0.41 & 0.76 & 0.53 & 0.97 & 0.49 & 1.09 & 0.34 & 0.98 \\
\hline 5 & 0.64 & 0.96 & 0.65 & 0.82 & 0.24 & 0.78 & 0.61 & 0.97 & 0.36 & 1.14 & 0.32 & 1.07 \\
\hline 6 & 0.74 & 0.94 & 0.52 & 0.79 & 0.46 & 0.72 & 0.57 & 0.96 & 0.53 & 1.08 & 0.38 & 1.02 \\
\hline
\end{tabular}

\subsection{Determination results and analysis of COD and BOD5}

It can be seen from Table 3 that the determination results of COD and BOD5 of water samples of six different locations and at different times was different. The value of COD was from $22.35 \mathrm{mg} / \mathrm{L}$ to $57.19 \mathrm{mg} / \mathrm{L}$, which was a big fluctuant data. But the value of BOD5 was from $1.12 \mathrm{mg} / \mathrm{L}$ to $3.56 \mathrm{mg} / \mathrm{L}$, which was a relatively stable data. We knew that some organic matter can be biodegraded, some organic matter can only be biodegraded partially, and some organic matter can not be biodegraded and has toxicity. Therefore, we could divide the organic matter in water into two parts, that is, biodegradable organic matter and non biodegradable organic matter. It was generally believed that COD can basically represent all organic matter in water and BOD5 was biodegradable organic matter in water. Therefore, the difference between COD and BOD5 can represent the organic matter in the non-biodegradable part of wastewater. This showed that the pollution of Hengshui Lake was mainly non-biodegradable organic matter pollution.

\subsection{Determination results and analysis of $\mathrm{NH}_{3}-\mathrm{N}$ and TN}

It can be seen from Table 4 that the determination results 
of $\mathrm{NH}_{3}-\mathrm{N}$ and $\mathrm{TN}$ of water samples of six different locations and at different times was different. The values of $\mathrm{NH}_{3}-\mathrm{N}$ were basically maintained at about $0.3-0.7$ $\mathrm{mg} / \mathrm{L}$. The values of $\mathrm{TN}$ were basically maintained at about $0.7-1.2 \mathrm{mg} / \mathrm{L}$. $\mathrm{NH}_{3}-\mathrm{N}$ refers to the nitrogen in the form of free ammonia $\left(\mathrm{NH}_{3}\right)$ and ammonium ion $\left(\mathrm{NH}^{4+}\right)$ in water. The nitrogen content of animal organic matter was generally higher than that of plant organic matter. In addition, nitrogen-containing organic matter in human and animal feces was very unstable and easied to decompose into ammonia. Therefore, when the content of ammonia nitrogen in water increased, it meant the combined nitrogen in the form of ammonia or ammonium ion. TN was the total amount of various forms of inorganic and organic nitrogen in water, which included inorganic nitrogen such as $\mathrm{NO}_{3}^{-}, \mathrm{NO}_{2}^{-}$and $\mathrm{NH}^{4+}$, and organic nitrogen such as protein, amino acid and organic amine. The standard limits of the basic items of TN of the surface water environmental quality standards for the Class III water was lower than 1.0 $\mathrm{mg} / \mathrm{L}$. This showed that the self purification capacity of Hengshui Lake water body was weaker.

\subsection{Determination results and analysis of calcium ion content, total hardness, chloride ion content, $\mathrm{pH}$ value and conductivity}

The determination results of calcium ion content, total hardness, chloride ion content, $\mathrm{pH}$ value and conductivity of water samples of six different locations and at different times was obtained. Calcium ion content was about $200 \mathrm{mg} / \mathrm{L}$, total hardness was about $400 \mathrm{mg} / \mathrm{L}$, chloride ion content was about $150-200 \mathrm{mg} / \mathrm{L}$, $\mathrm{pH}$ value was between 7-8, conductivity was about 1300-1700 us $/ \mathrm{cm}$. The water quality of the water samples had reached the criteria specified in Water Quality Standard for Drinking Water Source. So the water quality of Hengshui Lake was suitable for downstream as drinking water after purification through waterworks, but it must meet the sanitary standard of drinking water.

\subsection{Water quality evaluation of Hengshui Lake}

The ecological carrying capacity of the environment is the most important influencing factor of the environmental carrying capacity. The ecological carrying capacity refers to the amount of activities that can be accommodated under the premise that the natural environment of the lake do not degenerate in a certain period of time. Ecological capacity is based on the local original ecological quality, considering that the environment can completely absorb and purify the tourism pollutants produced by artificial places, and it is an indicator to measure the ecological carrying capacity [9]. There is a certain limit to the ability of automatic regulation and compensation of wetland ecological environment system. When the influence of intervention factors exceeds the endurance limit of the ecosystem, it means that the ecosystem is facing the crisis of imbalance and collapse. Therefore, protection of lake water quality must refer to control external pollution sources (factory sewage, domestic sewage, pesticide and fertilizer pollution, surface runoff pollution, atmospheric deposition pollution, etc.) and endogenous pollution (release of nutrients settling to the bottom of the lake). Environmental capacity is mainly determined by ecological capacity.

\section{Conclusions}

According to the data analysis results of COD, BOD5, $\mathrm{NH}_{3}-\mathrm{N}$, TN, TOC, TP, calcium ion content, total hardness, chloride ion content, $\mathrm{pH}$ value and conductivity of Hengshui Lake water samples, the water quality of Hengshui Lake in different regions and at different times was evaluated and analyzed. The values of TOC, COD and TN were comparatively higher. But the values of TP, BOD5 and $\mathrm{NH}_{3}-\mathrm{N}$ were comparatively lower. The data analysis results showed that the pollution of Hengshui Lake was mainly organic matter pollution, especially non-biodegradable organic matter pollution. The value of TN was higher than the Class III water, which showed that the self purification capacity of Hengshui Lake water body was weaker. Overall, the water quality of Hengshui Lake was better, but the treatment of organic pollution should be paid attention to.

The authors would like to acknowledge the Fundamental Research Project of Hebei Province (18964005D), the Open Foundation of Hebei Key Laboratory of Wetland Ecology and Conservation (No. hklk201911) and the Science and Technology Plan Project of Hebei Academy of Sciences (21704), for providing financial support for this project.

\section{References}

1. H. Li, Y. Hao, Wat. Sci. and Eng. Tec. 5, 10-12, (2009)

2. J. Liu, , Chi. Mar. 21, 211-212 (2016)

3. J. Li, J. Chi. Uni. (Nat. Sci. Edi.) 29, 10-12 (2013)

4. B. Shi, X. Li, J. Hengshui Uni. 14, 5-7, (2012)

5. H. Chang, Y. Fu, W. Pan, J. Hengshui Uni. 13, 1-3, (2011)

6. L. Zhang, R. Ouyang, Y. Fan, Mode. Rur. Sci. and Tec. 1, 70-71, (2015)

7. G. Liu, Mode. Rur. Sci. and Tec. 7, 72-73, (2013)

8. J. Han, Fis. Gui. Ric. 16, 14-15, (2007)

9. Y. Zhang, F. Guo, J. Nor. For. Coll. 26, 224-228, (2011) 